\title{
MENINGKATKAN HASIL BELAJAR MATEMATIKA SISWA MELALUI MODEL PEMBELAJARAN OPEN ENDED BERBASIS TRI KAYA PARISUDHA
}

\author{
I Pt Rian Nugraha Wiraharta ${ }^{1}$, Kadek Yudiana ${ }^{2}$, Ni Nyoman Kusmariyatni ${ }^{3}$ \\ 123 Prodi Pendidikan Guru Sekolah Dasar, Jurusan Pendidikan Dasar, Singaraja, Indonesia \\ E-mail: pt.rian.nugraha@undiksha.ac.id
}

\begin{abstract}
Abstrak
Penelitian eksperimen ini bertujuan untuk mengetahui pengaruh yang signifikan model pembelajaran Open Ended berbasis Tri Kaya Parisudha terhadap hasil belajar matematika siswa kelas V SD. Berdasarkan wawancara dan observasi, permasalahan pada pembelajaran matematika di lapangan yaitu kurangnya partisipasi siswa, kurangnya minat siswa dalam belajar, kurangnya sikap berpikir kritis siswa terhadap pemecahan masalah matematika, serta hasil belajar siswa sebagian besar dibawah KKM. Hal ini diakibatkan oleh kurangnya penggunaan model yang inovatif serta pembahasan permasalahan matematika dalam pembelajaran. Oleh karena itu, diperlukan penerapan model yang inovatif dalam pembelajaran. Penelitian ini dirancang dengan konsep nonequivalen post-test only control group design. 179 siswa kelas V SD ditetapkan sebagai populasi penelitian. Sampel pada penelitian ini terdiri dari 24 siswa pada kelompok eksperimen dan 25 siswa pada kelompok kontrol. Hasil tersebut diperoleh dari penentuan sampel melalui simple random sampling. Metode pengumpulan data yang digunakan adalah metode tes berupa essay/uraian yang berjumlah 10 butir. Sebelum digunakan, instrumen telah diujicobakan serta dilakukan uji validitas, reliabilitas, daya beda soal dan tingkat kesukaran soal. Setelah data dikumpulkan, data dianalisis menggunakan uji-t dengan hasil $t_{\text {hitung }}=24,63$ dan $t_{\text {tabel }}=2,01$. Kriteria pengujian menunjukan $t_{\text {hitung }}>t_{\text {tabel }}(24,63>2,01)$. Simpulan dari hasil analisis data dalam penelitian ini adalah terdapat pengaruh yang signifikan model pembelajaran Open Ended berbasis Tri Kaya Parisudha terhadap hasil belajar matematika siswa kelas V SD. Hasil penelitian memberikan dampak positif terhadap siswa dan mampu menjawab permasalahan yang ada. Hasil penelitian ini dapat menjadi rujukan dalam membangun kegiatan belajar mengajar yang lebih menarik dengan membahas konsep matematika melalui permasalahan terbuka.
\end{abstract}

Kata Kunci: Open Ended; Hasil Belajar; Matematika

\begin{abstract}
This experiment research aims to determinethe the effect of open ended learning model based on tri kaya parisudha on mathematics learning outcomes of fifth grade students of elementary school. Based on interviews and observations, problems in learning mathematics are lack of student participation, lack of student interest in learning, lack of students' critical thinking attitudes towards solving mathematical problems, and student learning outcomes are mostly under standard. This is caused by the lack of use of innovative models and the discussion of mathematical problems in learning. This research is designed by non-equivalent post-test only control group. Population in this research was 179 people fifth grade. After use simple random sampling, 24 students selected as experimental group, and 25 students selected as the control group. The method that used to get data is 10 items of essay tests. Before used, instrument has been trial tested and tested with formula of validity, reliability, power of different, and level of difficulty of the questions.After data collected, data was analyzed using t-test, the result of $\mathrm{t}$-count $=24.63$ and $\mathrm{t}$-table $=2.01$. The criteria show $\mathrm{t}$-count $>\mathrm{t}$-table $(24.63>2.01)$. The conclusion is there is a significant effect of open ended learning model based on tri kaya parisudha on mathematics learning outcomes of fifth grade students of elementary school in Gugus VI of Sukasada District, Buleleng Regency in the academic year $2019 / 2020$. The research results gave positive impact on students and solve the problem. Research result can be reference to build good mathematic learning.
\end{abstract}

Keywords: Open Ende; Learning Outcome; Mathematic

\section{PENDAHULUAN}

Matematika identik sebagai mata pelajaran yang membahas angka-angka serta perhitungan. Matematika adalah ilmu pengetahuan yang diperoleh dari kegiatan berpikir (bernalar) yang ditekankan pada kegiatan dalam dunia rasio (penalaran), bukan dari hasil observasi (Rahmah, 2013). Pengalaman manusia dalam dunia empiris membentuk suatu konsep matematika. Selanjutnya pengalaman tersebut diproses dalam dunia rasio, dianalisis dengan penalaran di dalam struktur kognitif hingga menghasilkan 
konsep-konsep matematika. Agar konsep-konsep yang terbentuk mudah dipahami dan dimanipulasi secara tepat oleh orang lain, digunakan bahasa matematika yang bersifat universal/ global (Rahmah, 2013). Kegiatan menalar melalui menelaah bentuk, struktur, susunan, besaran, dan konsep-konsep yang abstrak yang saling berhubungan satu dengan yang lainnya merupakan sumber ilmu pengetahuan pada matematika. Pembelajaran matematika merupakan upaya pengorganisasian lingkungan demi terciptanya situasi belajar bagi peserta didik melalui rancangan kegiatan yang didalamnya terdapat proses mental dan fisik yang didapatkan dari interaksi antar peserta didik, peserta didik dengan pendidik, lingkungan, dan sumber belajar lainnya dalam menelaah bentuk, struktur, susunan, besaran, dan konsep-konsep yang abstrak serta hubungannya, untuk mencapai kompetensi dasar tertentu (Amir, 2014). Pelaksanaan pembelajaran matematika memiliki tujuan dan karakteristik masing-masing sesuai dengan jenjang pendidikan.

Pembelajaran matematika yang dilaksanakan di sekolah dasar tentunya harus disesuaikan pada karakteristik anak usia sekolah dasar yaitu pada tahap operasional konkret. Kondisi kognitif anak pada tahap ini ditandai dengan berkembangnya sistem pemikiran logis berdasarkan apa yang kelihatan nyata/konkret. Pada kurikulum matematika SD, konsep matematika di SD terbagi dalam tiga kelompok,yaitu: penanaman konsep dasar, pemahaman konsep, dan pembinaan keterampilan. Penanaman konsep dasar adalah kegiatan pengenalan suatu konsep baru kepada siswa. Selanjutnya pemahaman konsep adalah pendalaman dari penanaman konsep yang telah dilakukan. Dari tahapan/proses yang dilakukan tersebut, akan bermuara pada terampilnya siswa dalam mengaplikasikan konsep matematika yang telah dipelajari ke dalam kehidupan sehari-hari (Heruman, 2007). Rahmadani dan Anugraheni menyatakan tujuan pembelajaran matematika di SD secara umum adalah tercapainya peserta didik yang memiliki kemampuan menggunakan matematika dengan terampil (Rahmadani \& Anugraheni, 2017). Selanjutnya tujuan pembelajaran matematika di SD secara khusus yaitu meningkatkan pemahaman konsep matematika, memahami penjelasan mengenai keterkaitan antar konsep, memakai penalaran pada pola dan sifat, melaksanakan manipulasi matematika dalam generalisasi, melakukan penyusunan bukti, menjelaskan gagasan dan pernyataan matematika, menyusun penecahan masalah, dan memiliki sikap menghargai manfaat matematika dalam kehidupan sehari-hari. Selanjutnya Gunantara, Suarjana, \& Riastini (2014) menjabarkan tujuan pembelajaran matematika di SD adalah sebagai berikut. Pertama, anak memiliki sikap aktif terlibat dalam pembelajaran dan memanfatkan kesempatan dalam mengungkapkan ide-ide yang dimiliki. Kedua, melatih diri berperilaku sesuai dengan tahapan dan karakteristik yang terindentifikasi. Ketiga, mampu berproses dari tahap berpikir yang sangat konkret menuju ke tahapan selanjutnya yang lebih abstrak. Keempat, menguasai penggunaan simbol-simbol representasi yang bersifat lebih abstrak.Kelima, membentuk sikap logis, kritis, kreatif, cermat dan disiplin.

Pembelajaran matematika di sekolah dasar yang dilaksanakan oleh guru masih kurang efektif. Pada pengajaran mata pelajaran ini, guru belum banyak mengikutsertakan siswa untuk bersikap aktif dan kreatif pada proses pembelajaran. Hal tersebut tentunya mempengaruhi hasil belajar yang diperoleh oleh siswa. Hasil belajar adalah perolehan atau taraf kemampuan yang dilimiki atau dicapai oleh siswa setelah mengikuti proses pembelajaran dalam periode atau waktu tertentu. Hasil belajar yang dimaksud adalah dari aspek kognitif, yaitu berupa nilai angka yang diperoleh siswa. Berdasarkan hasil wawancara dengan wali kelas V yang ada pada Gugus VI Kecamatan Sukasada Kabupaten Buleleng pada tanggal 21, 22 dan 23 Oktober 2019 diperoleh beberapa informasi yang dikemukakan. Guru mengatakan masih banyak siswa yang memperoleh nilai dibawah KKM. Hal tersebut bersumber dari berbagai permasalahan dan faktor-faktor tertentu. Pertama, siswa belummenunjukan partisipasi yang tinggi pada saat berlangsungnya proses belajar mengajar. Kedua, siswa belum dapat berpikir kritis dalam memecahkan masalah matematika. Ketiga, minat siswa untuk belajar cenderung kurang. Keempat, guru masih jarang dalam memanfaatkan model-model pembelajaran inovatif dan alat peraga atau media pembelajaran yang relevan. Permasalahan tersebut sering muncul dan dikemukakan oleh guru karena guru belum sepenuhnya dapat melaksanakan pembelajaran yang sesuai dengan masalah yang dihadapi siswa.Penelitian yang sebelumnya pernah dilakukan belum sepenuhnya dipahami oleh guru karena literasi guru mengenai penelitian-penelitian terdahulu masih kurang.Oleh karena itu, penelitian ini masih memiliki urgensi untuk dilaksanakan.

Selain melakukan proses wawancara, juga dilaksanakan observasi proses belajar mengajar mata pelajaran matematika di kelas V yang dilaksanakan pada tanggal 21, 22, dan 23 Oktober 2019. Berikut adalah beberapa permasalahan yang menyebabkan rendahnya hasil belajar siswa yang diperoleh dari hasil observasi.Pertama,guru jarang menerapkan model pembelajaran ketika pembelajaran matematika 
berlangsung, hal ini ditandai dengan proses pembelajaran di dalam kelas yang lebih didomonasi guru sehingga siswa cenderung cepat bosan dalam proses belajar. Kedua, siswa kurang menunjukan sikap semangat dalam mengikuti pembelajaran, hal tersebut terlihat dari partisipasi siswa yang kurang dalam berdiskusi dan merespons pertanyaan yang diberikan guru serta kurangnya minat siswa untuk mengajukan sebuah pertanyaan.Ketiga, guru jarang menyelipkan berbagai contoh permasalahan yang nyata terkait pembelajaran matematika yang diajarkan, hal ini terlihat pada penyajian materi hanya terfokus pada teori semata.

Berdasarkan hasil pencatatan dokumen yang diperoleh dari masing-masing wali kelas $\mathrm{V}$ di Gugus VI Kecamatan Sukasada, pencapaian KKM mata pelajaran matematika pada nilai ulangan tengah semester (UTS) ganjil siswa kelas V tahun pelajaran 2019/2020 masih sebagian besar belum mencapai KKM. Dari 179 siswa yang terdaftar, hanya 74 siswa atau 41, 34\% siswa yang mampu mencapai KKM. Dengan demikian, dapat dibuktikan bahwa KKM yang telah ditentukan oleh sekolah belum dapat dicapai oleh sebagian besar siswa.Oleh karena itu, diperlukan adanya solusi dalam menghadapi permasalahan tersebut, serta membuat pembelajaran agar berjalan lebih maksimal.Salah satunya adalah mengaplikasikan model pembelajaran yang inovatif. Salah satu dari banyak model inovatif yang dapat diaplikasikan adalah model pembelajaran open ended. Model ini sangat cocok diterapkan pada pembelajaran matematika.

Kurangnya minat siswa di kelas V Gugus VI Kecamatan Sukasada dalam mengikuti pembelajaran matematika disebabkan oleh kurang efektifnya pembelajaran yang dilaksanakan oleh guru. Pada saat berlangsungnya pembelajaran, guru menyampaikan suatu materi dengan cara yang monoton dan jarang menerapkan model pembelajaran inovatif. Model pembelajaran adalah pedoman dalam merancang aktivitas belajar siswa sehingga dapat membantu siswa dalam mendapatkan informasi, ide, keterampilan, cara berpikir, dan mengekspresikan ide (Marliani, 2015). Selain itu model pembelajaran juga diartikan sebagai strategi-strategi yang berdasar pada teori-teori dan penelitian yang terdiri dari rasional, seperangkat langkah-langkah dan tindakan yang dilakukan guru dan siswa, sistem pendukung pembelajaran dan metode evaluasi atau sistem penilaian perkembangan belajar siswa (Sundari, 2016). Pemilihan model pembelajaran yang tepat oleh guru dilakukan untuk meningkatkan partisipasi, membangkitkan semangat dan melatih pola pikir kritis siswa dalam pembelajaran.Salah satu model yang digunakan adalah model pembelajaran Open Ended. Model Open Ended adalah pembelajaran yang menyajikan permasalahan, dimana permasalahan tersebut dapat dipecahkan melalui lebih dari satu penyelesaian yang benar. Problem yang disajikan yang memiliki multijawaban itu disebut juga open ended problem atau soal terbuka (Biliya, 2015). Sementara Ardiyanti menyatakan "Model pembelajaran matematika berorientasi open ended problem merupakan pembelajaran yang dimodifikasi dari model pembelajaran berbasis masalah, hanya saja masalah yang disajikan kepada siswa diorientasikan pada masalah open ended dengan tetap mengacu pada model pembelajaran berbasis masalah, dimana jenis masalah yang digunakan adalah masalah terbuka" (Ardiyanti, Suarjana, \& Garminah, 2013). Kemudian Nuryanti jugamengemukakan bahwa "open ended adalah suatu model pembelajaran yang diformulasikan memiliki multi jawaban (mempunyai beberapa penyelesaian) atau sering disebut juga problem terbuka"(Nuryanti, 2018). Model pembelajaran ini merupakan salah satu model inovatif yang dapat menjawab permasalahan yang ada. Hal tersebut dibuktikan dari beberapa hasil penelitian yang telah dilakukan sebelumnya. Seperti pada hasil penelitian yang dilaksanakan oleh Yunus pada tahun 2015menyimpulkan bahwa hasil belajar matematika siswa yang mengikuti pembelajaran open ended lebih tinggi dibandingkan dengan siswa yang mengikuti pembelajaran konvensional(Yunus, 2015). Kemudian penelitian yang telah dilakukan oleh Ariani menyimpulkan bahwa terdapat pengaruh implementasi open ended problem dalam pembelajaran matematika terhadap kemampuan pemecahan masalah dengan pengendalian kemampuan penalaran abstrak(M Desi Ariani, M Candiasa, 2014). Selain itu, Noviyanajuga menunjukan bahwa model open ended berpengaruh terhadap kemampuan pemecahan masalah matematis siswa (Noviyana, 2018). Secara umum sintaks model pembelajaran matematika berorientasi open ended problem ini terdiri dari limatahap. Tahap-tahap tersebut adalah: orientasi siswa kepada masalah open ended; mengkondisikan siswa untuk belajar memecahkan masalah open ended; membimbing penyelidikan individual maupun kelompok; mengembangkan dan menyajikan hasil karya; menganalisis dan mengevaluasi proses pemecahan masalah open ended(Ardiyanti et al., 2013). Sementara Delyana juga mengemukakan langkah-langkah umum pembelajaran open ended yaitu: pembelajaran diawali dengan pemberian permasalahan terbuka oleh guru, siswa melakukan beragam aktivitas untuk menjawab permasalahan yang diberikan, siswa diberikan waktu yang cukup untuk mengeksplorasi masalah, siswa membuat rangkuman dari proses penemuan yang mereka lakukan, 
diskusi kelas mengenai strategi dan pemecahan dari masalah serta penyimpulan dengan bimbingan guru (Delyana, 2015).

Model pembelajaran open ended akan lebih maksimal jika berbasis dengan Tri Kaya Parisudha. Berasal dari kata "Tri" yang berarti tiga, "Kaya" berarti perilaku atau perbuatan, dan "Parisudha" yang berarti baik, bersih, suci atau disucikan, Tri Kaya Parisudha berarti tiga perbuatan yang harus disucikan. Adapun bagiannya yaitu manacika (perilaku yang berlandaskan pikiran yang baik, suci dan benar), wacika (perilaku yang berlandaskan perkataan yang baik, suci dan benar), dan kayika (perilaku yang berlandaskan perbuatan yang baik, suci dan benar) (Parmanjaya, 2017). Tri Kaya Parisudha merupakan salah satu ajaran yang universal mengenai konsep etika sebagai landasan berperilaku yang baik dan benar bagi masyarakat Bali. Pendapat Suardika menyatakan bahwa " Tri Kaya Parisudha berarti tiga sikap atau perbuatan yang disucikan. Sebagai bagian dari ajaran etika dalam agama Hindu, Tri Kaya Parisudha dapat memberikan tuntunan atau jalan dalam mencapai kedamaian dan keharmonisan dalam kehidupan"(Suardika, 2016). Integrasi Tri Kaya Parisudha dalam pembelajaran secara tidak langsung dapat membimbing siswa untuk berpikir, bersikap dan memahami konsep pembelajaran dengan baik (Artawan \& Ardiawan, 2018). Model Open Ended berbasis Tri Kaya Parisudha dapat diaplikasikan dalam setiap proses pembelajaran. Dalam proses pembelajaran, intelegensi individu bukan satu-satunya sesuatu yang diperlukan, melainkan diperlukan juga skill dalam bekerjasama dengan seluruh pihak dalam pembelajaran. Kerjasama yang baik akan terjalin ketika siswa berkata, berpikir dan berperilaku yang baik. Tiga karakter yang ditanamkan dalam penerapan model ini yaitu; berpikir baik (Manacika), berkata baik (Wacika), dan berbuat baik (Kayika).Nilai-nilai karakter Tri Kaya Parisudha yang dapat ditanamkan seperti religius, berpikir positif, berkata jujur, sopan, memiliki rasa kasih sayang, berbuat jujur, disiplin, peduli sesama dan tolong menolong. Dengan menggunakan berbasis Tri Kaya Parisudha dalam pembelajaran akan menjadikan proses pembelajaran menjadi lebih menarik dan menyenangkan dan juga membantu siswa menanamkan karakter atau kepribadian siswa yang lebih baik dan mampu bekerjasama dalam memahami materi yang dibahas. Dengan demikian, hasil belajar matematika siswa dapat menjadi lebih baik.Dalam pelaksanaanya guru diarahkan untuk menguasai lebih dalam model yang diaplikasikan agar dapat diaplikasikan kembali secara berkelanjutan.

Kebaharuan yang ada dalam penelitian ini yaitu adanya integrasi Tri Kaya Parisudha dengan model pembelajaran open ended. Konsep Tri Kaya Parisudhadapat menuntun siswa dalam berpikir, berkata dan berbuat yang baik sehingga dapat memperlancar proses pembelajaran dan membantu siswa dalam meningkatkan kemampuan dalam merespons hal yang dibahas dalam pembelajaran(Somawati \& Diantary, 2019). Dimodifikasi dari Khalistin dan Hidayanto, sintaks model pembelajaran open ended berbasisTri Kaya Parisudha meliputi kegiatan awal, kegiatan inti dan kegiatan penutup(Khalistin \& Hidayanto, 2013). Kegiatan inti memuat pembentukan kelompok dan pemberian masalah oleh guru, siswa mengeksplorasi masalah, guru merekam respons siswa, pembahasan respons siswa, dan meringkas apa yang telah dipelajari. Pada langkah pemberian masalah, guru memberi masalah kepada masing-masing kelompok dalam bentuk Lembar Kegiatan Siswa (LKS) maupun pemberian secara langsung. Kelompok yang dibentuk merupakan kelompok kecil.Siswa mencari anggota kelompoknya dengan sikap yang tertib (Kayika) dan melakukan interaksi yang baik dalam kelompok dengan kata yang sopan dan santun (Wacika). Pada langkah eksplorasi masalah yang dilakukan oleh siswa, siswa dalam masing-masing kelompok mendiskusikan setiap permasalahan yang terdapat dalam LKS atau masalah yang telah diberikan. Siswa berfikir dengan jernih dan berdiskusi dengan rasa saling menghargai (Manacika).Siswa juga melakukan interaksi yang baik dalam kelompok dengan kata yang sopan dan santun (Wacika). Guru memantau setiap kelompok dan dapat mengarahkan siswa untuk dapat menyelesaikan setiap permasalahan dengan baik.Pada langkah merekam respon siswa, guru menghimpun data/mencatat respon masing-masing kelompok mengenaicara pengerjaan, banyak alternatif pengerjaan, jawaban yang diperoleh dan banyak jawaban yang mungkin yang diperoleh. Pembahasan respon siswa dilakukan dalam diskusi kelas yang diikuti oleh semua kelompok dan dipandu oleh guru. Siswa menjaga ketertiban dalam dikusi (Kayika). Guru mengarahkan semua kelompok untuk aktif dalam jalannya diskusi. Untuk mengawali pembahasan pada suatu permasalahan, guru menunjuk salah satu kelompok, meminta secara sukarela kelompok yang ingin menyampaikan jawaban dari kelompok mereka atau menanyakan jawaban masing-masing kelompok satu per satu (Wacika). Setelah jawaban dari kelompok pertama disampaikan, guru meminta pendapat dari kelompok lain mengenai kebenaran dari jawaban kelompok pertama atau meminta kelompok lain yang memiliki jawaban yang berbeda atau ingin menambahkan jawaban untuk menyampaikan jawabannya (Wacika dan Manacika). Pada akhir pembahasan setiap permasalahan, 
guru menekankan jawaban yang benar dan memberikan penjelasan mengenai jawaban yang salah. Tahap terakhir, guru meminta siswa untuk meringkas setiap permasalahan yang telah dibahas dalam diskusi sebelumnya (Manacika).

Tujuan dalam penelitian ini yaitu untuk mengetahui adanya pengaruh yang signifikan model pembelajaran Open Ended berbasis Tri Kaya Parisudha terhadap hasil belajar matematika siswa kelas V di SD Gugus VI Kecamatan Sukasada Kabupaten Buleleng tahun pelajaran 2019/2020.

\section{METODE}

Penelitian ini termasuk penelitian eksperimen semu (Quasi Eksperimental Research). Penelitian eksperimen ini dilakukan dengan menggunakan rancangan non-equivalent post-test only control group design. Adapun pola desain dari non-equivalent post-test only control group design disajikan tabel 1.

Tabel 1. Desain Penelitian Non Equivalent Post-test Only Control Group Design

\begin{tabular}{ccc}
\hline Kelompok & Perlakuan & Post-test \\
\hline Eksperimen & $\mathrm{X}_{1}$ & $\mathrm{O}_{1}$ \\
Kontrol & - & $\mathrm{O}_{2}$ \\
\hline
\end{tabular}

(dalam Agung, 2014)

Berdasarkan tabel 1, kelompok eksperimen diberikan perlakuan menggunakan model pembelajaran Open Ended berbasis Tri Kaya Parisudha $\left(\mathrm{X}_{1}\right)$. Perlakuan yang diberikan pada penelitian ini berupa pertemuan tatap muka sebanyak 7 kali sesuai dengan kompetensi dasar yang ditentukan.Setelah diberikan perlakuan selanjutnya kelompok eksperimen diberikan tes akhir $\left(\mathrm{O}_{1}\right)$, sedangkan kelompok kontrol tidak diberikan perlakuan menggunakan model pembelajaran Open Ended berbasis Tri Kaya Parisudha. Kelompok kontrol juga diberikan tes akhir $\left(\mathrm{O}_{2}\right)$.

Adapun prosedur yang telah dilakukan dalam penelitian ini terdiri dari tiga tahap yaitu tahap persiapan, tahap pelaksanaan, dan tahap akhir eksperimen. Tahap persiapan terdiri atas; penjajagan ke sekolah tujuan dan melakukan observasi dan wawancara, mencari informasi mengenai hasil belajar siswa, menentukan sampel penelitian berdasarkan populasi yang ada, penyusunan rencana pelaksanaan pembelajaran (RPP), mempersiapkan segala sarana yang diperlukan dalampembelajaran dengan menggunakan model pembelajaran Open Ended berbasis Tri Kaya Parisudha, melakukan konsultasi RPP dengan guru kelas, merancang instrumen penelitian, uji judjes instrument dan ujicoba instrumen. Tahap pelaksanaan eksperimen dilakukan dengan memberikan perlakuan pada kelas eksperimen berupa pembelajaran dengan model pembelajaran Open Ended berbasis Tri Kaya Parisudha sebanyak 7 kali di kelas eksperimen dan memantau pembelajaran di kelas kontrol. Tahap akhir eksperimen terdiri atas memberikan tes akhir (post-test) pada kelas eksperimen dan kelas kontrol untuk mendapatkan data, menganalisis data hasil belajar siswa dan pengujian hipotesis.

Populasi pada penelitian ini adalah seluruh siswa kelas V SD di Gugus VI Kecamatan Sukasada Kabupaten Buleleng yang berjumlah 8 rombel dari 7 sekolah yang berjumlah 179 orang siswa. Untuk mengetahui kesetaraan kemampuan siswa kelas V di SD Gugus VI Kecamatan Sukasada Kabupaten Buleleng, telah dilakukan uji kesetaraan kemampuananggota populasi dengan cara menganalisis nilai ulangan tengah semester mata pelajaran matematika menggunakan rumus anava satu jalur. Berdasarkan hasil uji kesetaraan dengan menggunakan bantuan Microsoft Excel 2007, di peroleh F hitung sebesar 0,214. Selanjutnya F hitung akan dibandingkan dengan $\mathrm{F}$ tabel dengan taraf signifikan $5 \%$. Hasil penghitungan tersebut menunjukkan bahwa $\mathrm{F}$ hitung lebih kecil daripada $\mathrm{F}$ tabel $(0,213<$ 2,09). Dengan demikian, dapat disimpulkan bahwa tidak terdapat perbedaan hasil ulangan tengah semester mata pelajaran matematika siswa kelas V SD di Gugus VI Kecamatan Sukasada Kabupaten Buleleng. Hasil uji kesetaraan populasi disajikan dalam tabel 2 sebagai berikut.

Tabel 2.Ringkasan Uji Kesetaraan Populasi Penelitian

\begin{tabular}{ccccccc}
\hline $\begin{array}{c}\text { Sumber } \\
\text { Variasi }\end{array}$ & JK (SS) & $\begin{array}{c}\text { Db } \\
\text { (df) }\end{array}$ & $\begin{array}{c}\text { RJK } \\
\text { (MS) }\end{array}$ & Fh & $\begin{array}{c}\text { Ftab } \\
\mathbf{5 \%}\end{array}$ & Keputusan \\
\hline antar A & 140,942 & 7 & 20,134 & 0,213 & 2,09 & Non Signifikan \\
\hline $\begin{array}{c}\text { Dalam } \\
\text { (error) }\end{array}$ & $16.153,236$ & 171 & 94,463 & - & - & - \\
\hline
\end{tabular}


Teknik penentuan sampel yang digunakan dalam penelitian ini adalah simple random sampling atau sampel acak sederhana dengan teknik undian. Dalam penelitian ini sampel yang diacak/di random adalah kelas, karena perubahan kelas tidak memungkinkan untuk dilakukan. Hasil pengundian menampilkan dua sekolah yang muncul yaitu SDN 1 Panji Anom Rombel A dan SDN 4 Panji Anom. Selanjutnya hasil tersebut diundi kembalisehingga menetapkan kelas V/A SDN 1 Panji Anom sebagai kelompok eksperimen dan kelas V SDN 4 Panji Anom ditetapkan sebagai kelas kontrol. Kelompok eksperimen mendapat perlakuan berupa model pembelajaran Open Ended berbasis Tri Kaya Parisudha, sementara kelompok kontrol tidak mendapat perlakuan, dengan kata lain tidak dibelajarkan menggunakan model pembelajaran Open Ended berbasis Tri Kaya Parisudha.

Instrumen yang digunakan dalam penelitian ini berdasarkan metode yang digunakan adalah tes hasil belajar matematika kelas V. Tes hasil belajar matematika yang digunakan adalah bentuk tes essay/uraian. Metode tes dilakukan dengan membagikan sejumlah tes, untuk mengukur hasil belajar matematika siswa. Tes pada penelitian ini mengukur kemampun siswa dalam ranah kognitif. Setiap item soal essay atau uraian dapat dijawab oleh siswa dengan cara menjawab yang telah ditentukan yaitu menggunakan teori polya yang menuliskan diketahui, ditanyakan dan jawaban. Setiap item diberi skor 1-4 sesuai dengan rubrik penilaian yang telah ditentukan. Jika siswa tidak menjawab butir soal tersebut, maka akan mendapat skor 0. Kemudian skor setiap item dijumlahkan dan jumlah tersebut merupakan skor variabel hasil belajar matematika. Tes essay/uraian yang digunakan disusun berdasarkan atas susunan taksonomi Bloom yang sudah direvisi.

Instrumen yang telah digunakan dalam penelitian ini telah memenuhi syarat sebagai instrumen yang baik. Hal tersebut dikarenakan sebelum diaplikasikan, instrumen telah melewati serangkaian uji coba dan beberapa pengujian instrumen. Dalam penyusunan instrumen (tes), telah meminta masukan dari para ahli (expert judgement). Uji coba instrumen penelitian dilakukan untuk mendapat gambaran secara empiris apakah seluruh instrumen layak digunakan sebagai instrumen penelitian. Kelayakan instrumen telah dianalisis dengan menggunakan uji validitas tes (isi dan butir), reliabilitas tes, taraf kesukaran tes, dan daya beda tes. Uji validitas adalah serangkaian tes untuk menentukan apakah suatu tes telah layak untuk mengukur kemampuan testee dari tes tersebut (Riyani, Maizora, \& Hanifah, 2017). Hasil uji validitas isi menunjukan koefisien validitas isi 1,0, yang artinya tes yang diuji termasuk ke dalam kriteria validitas isi sangat tinggi. Selanjutnya hasil pengujian validitas butir menunjukan 10 butir soal yang diujicobakan memenuhi kriteria valid. Uji reliabilitas tes dilakukan untuk mengetahui tingkat ketepatan dan keajegan atau konsistensi skor tes (Kadir, 2015). Hasil pengujian reliabilitas tes menunjukan koefesien reliabilitas tes sebesar 0,8888 yang artinya tes yang diujicobakan memenuhi kategori reliabilitas tes sangat tinggi. Uji daya beda tes adalah cara mengetahui tingkat kemampuan suatu soal untuk membedakan antara siswa yang pandai dengan siswa yang kurang pandai (Mujianto, 2017). Koefesien daya beda tes secara keseluruhan menunjukan angka 0,7473 yang artinya tes secara keseluruhan memenuhi kategori daya beda tes yang sangat baik. Daya beda masing-masing butir tes menunjukan hasil 8 butir memenuhi kriteria sangat baik, dan 2 butir memenuhi kategori baik. Tingkat kesukaran butir tes menunjukan 8 butir tes memenuhi kategori sedang, 1 butir memenuhi kategori mudah dan 1 butir memenuhi kategori sukar.

Analisis data merupakan kegiatan yang dilakukan setelah seluruh responden atau sumber data lainnya telah terkumpul. Data yang dikumpulkan dalam penelitian ini adalah data hasil belajar matematika siswa kelas V SD. Data yang telah dikumpulkan dianalisis dengan menggunakan metode analisis data kuantitatif. Analisis data kuantitatif yaitu analisis data yang dapat diukur dalam skala numerik atau data-data yang disajikan dalam bentuk angka-angka. Teknik analisis data yang dipakai adalah statistik deskriptif dan statistik inferensial.Analisis statistik deskriptif berfungsi untuk mengelompokkan data, menyelesaikan, memaparkan, serta menyajikan hasil olahan. Statistik deskriptif yang digunakan dalam penelitian ini yaitu nilai rata-rata (mean), median (nilai tengah), modus, standar deviasi (SD), varians, dan PAP skala lima. Selanjutnya statistik inferensial berfungsi untuk menggeneralisasi hasil penelitian yang dilakukan pada sampel bagi populasi. Statistik inferensial yang digunakan dalam penelitian ini adalah uji prasyarat yang meliputi uji normalitas sebaran data dan uji homogenitas varians serta uji hipotesis dengan uji-t. 


\section{HASIL DAN PEMBAHASAN}

Hasil belajar matematika kelompok eksperimen diperoleh dari data post test yang diberikan kepada 24 orang siswa yang sebelumnya mendapat perlakuan berupa model pembelajaran Open Ended berbasis Tri Kaya Parisudha. Data tersebut menunjukan nilai tertinggi adalah 97,5 dan nilai terendah 47,5. Nilai rata-rata (mean) hasil belajar siswa kelompok eksperimen adalah 76,75.jika dimasukan ke dalam PAP skala lima kelompok eksperimen maka memenuhi kriteria sangat tinggi. Hasil belajar matematika kelompok kontrol diperoleh dari data post test yang diberikan kepada 25 orang siswa yang sebelumnya tidak mendapat perlakuan berupa model pembelajaran Open Ended berbasis Tri Kaya Parisudha. Data tersebut menunjukan nilai tertinggi adalah 90 dan nilai terendah 40.Nilai rata-rata (mean) hasil belajar siswa kelompok kontrol adalah 64,76. Jika dimasukan ke dalam PAP skala lima kelompok kontrol maka memenuhi kriteria sedang. Jika dilihat berdasarkan rata-rata (mean), hasil belajar matematika siswa kelompok eksperimen lebih tinggi dari hasil belajar matematika kelompok kontrol $(76,75>64,76)$. Hasil analisis statistik deskriptif secara mendetail disajikan dalam tabel 03 sebagai berikut.

Tabel 3. Hasil Analisis Statistik Deskriptif

\begin{tabular}{lcc}
\hline \multicolumn{1}{c}{ Statistik } & \multicolumn{2}{c}{ Hasil Belajar Matematika Siswa } \\
& Kelompok Eksperimen & Kelompok Kontrol \\
\hline Nilai Tertinggi & 97,5 & 90 \\
Nilai Terendah & 47,5 & 40 \\
Range & 51 & 51 \\
Mean & 76,75 & 64,76 \\
Median & 74,71 & 64,25 \\
Modus & 78,7 & 66,5 \\
Standar Deviasi & 12,23 & 12,17 \\
Varians & 149,57 & 148,11 \\
\hline
\end{tabular}

Pengujian prasyarat terhadap sebaran data terdapat dua bagian, yaitu uji normalitas sebaran data dan uji homogenitas varians yang dilakukan pada data hasil belajar matematika kelompok eksperimen dan kelompok kontrol. Pengujian ini dilakukan untuk menentukan langkah selanjutnya pada uji hipotesis. Uji normalitas berfungsi untuk menentukan dan membuktikan frekuensi data hasil penelitian benar-benar berdistribusi normal. Uji homogenitas varians dilakukan untuk mengetahui apakah kedua sampel dinyatakan homogen

Uji normalitas telah dilakukan terhadap data post test hasil belajar matematika kelompok eksperimen dan kelompok kontrol. Uji normalitas sebaran data yang digunakan adalah rumus ChiKuadrat $\left(X^{2}\right)$ dengan kriteria pengujian data berdistribusi normal jika $X^{2}$ hitung $<X^{2}$ tabel pada taraf signifikansi $5 \%$ dengan $\mathrm{dk}=$ jumlah baris -1 . Jika $X^{2}$ hitung $>X^{2}$ tabel maka data tidak berdistribusi normal. Berdasarkan perhitungan yang telah dilakukan dengan menggunakan rumus Chi-Kuadrat, diperoleh $X^{2}$ hitung pada kelompok eksperimen adalah 1,43 dan $X^{2}$ tabel dengan taraf signifikansi $5 \%$ dan $\mathrm{db}=5$ adalah 11,07. Hal tersebut menunjukan $X^{2}$ hitung hasil belajar matematika kelompok eksperimen lebih kecil dari $X^{2}$ tabel $\left(X^{2}\right.$ hitung $<X^{2}$ tabel $)$ sehingga data hasil belajar kelompok eksperimen berdistribusi normal. Selanjutnya $X^{2}$ hitung pada kelompok kontrol adalah 1,12 dan $X^{2}$ tabel dengan taraf signifikansi $5 \%$ dan $\mathrm{db}=$ 5 adalah 11,07 . Hal ini berarti $X^{2}$ hitung hasil belajar matematika kelompok kontrol lebih kecil dari $X^{2}$ tabel $\left(X^{2}{ }_{\text {hitung }}<X^{2}\right.$ tabel $)$ sehingga data hasil belajar pada kelompok kontrol berdistribusi normal. Untuk memperjelas pengamatan mengenai hasil uji normalitas sebaran data yang telah dilakukan, dapat dilihat dalam tabel 4 tentang rangkuman hasil uji normalitas sebaran data hasil belajar matematika kelompok eksperimen dan kontrol.

Tabel 4. Rangkuman Hasil Uji Normalitas Sebaran Data

\begin{tabular}{lccc}
\hline \multicolumn{1}{c}{ Kelompok Data } & $\mathbf{X}^{2}$ hitung & $\begin{array}{c}\text { Nilai Kritis dengan Taraf } \\
\text { Signifikansi 5\% }\end{array}$ & Status \\
\hline Post-test Eksperimen & 1,43 & 11,07 & Normal \\
Post-test Kontrol & 1,12 & 11,07 & Normal \\
\hline
\end{tabular}


Uji homogenitas varians dilakukan terhadap data hasil belajar matematika siswa kelompok eksperimen dan kelompok kontrol. Uji homogenitas varians dilakukan untuk mengetahui apakah kedua sampel dinyatakan homogen. Dalam uji homogenitas, data dikatakan homogen jika $F_{\text {hitung }}<F_{\text {tabel. }}$ Dari perhitungan yang dilakukan, diperoleh $\mathrm{F}_{\text {hitung }}$ homogenitas hasil belajar matematika siswa adalah 1,01 sedangkan $F_{\text {tabel }}$ pada taraf signifikan 5\% dengan df1 = k-1 =2-1=1, dan df2 = $\mathrm{n}-\mathrm{k}=49-2=47$, didapatkan harga $\mathrm{F}$ tabel sebesar 4,05. Hasil tersebut menunjukan F hitung $<\mathrm{F}$ tabel, dapat disimpulkan bahwa kedua kelompok data tersebut homogen. Untuk mempermudah pengamatan, hasil perhitungan uji homogenitas varians disajikan dalam table 5 dibawah ini.

Tabel 5. Rangkuman Hasil Uji Homogenitas Varians

\begin{tabular}{|c|c|c|c|c|c|c|c|}
\hline Kelompok Data & Varians & df1 & df2 & $\begin{array}{c}\text { Taraf } \\
\text { Signifikansi }\end{array}$ & Fhitung & Ftabel & Keterangan \\
\hline Kelompok & 149,57 & & & & & & \\
\hline $\begin{array}{l}\text { Eksperimen } \\
\text { Kelompok } \\
\text { Kontrol }\end{array}$ & 148,11 & 1 & 47 & $5 \%$ & 1,01 & 4,05 & Homogen \\
\hline
\end{tabular}

Hasil uji normalitas sebaran data dan uji homogenitas varians diperoleh data kedua kelompok sampel berdistri normal dan bersifat homogen. Untuk mengetahui pengaruh model pembelajaran Open Ended berbasis Tri Kaya Parisudha terhadap hasil belajar matematika siswa, telah dilakukan pengujian terhadap hipotesis dengan menggunakan uji-t dengan rumus polled varians. Hipotesis yang diuji dalam penelitian ini adalah sebagai berikut. $\mathrm{H}_{0}$ : tidak terdapat pengaruh yang signifikan model pembelajaran Open Ended berbasis Tri Kaya Parisudha terhadap hasil belajar matematika siswa kelas V SD Gugus VI Kecamatan Sukasada Kabupaten Buleleng Tahun Pelajaran 2019/2020. $\mathrm{H}_{1}$ :terdapat pengaruh yang signifikan model pembelajaran Open Ended berbasis Tri Kaya Parisudha terhadap hasil belajar matematika siswa kelas V SD Gugus VI Kecamatan Sukasada Kabupaten Buleleng Tahun Pelajaran 2019/2020. Kriteria pengujian adalah $\mathrm{H}_{0}$ ditolak jika $t_{\text {hitung }}>t_{\text {tabel }}$, dimana $t_{\text {tabel }}$ diperoleh dari tabel distribusi $t$ pada taraf signifikansi $5 \%$ dengan derajat kebebasan $\mathrm{db}=\mathrm{n} 1+\mathrm{n} 2-2$. Hasil analisis uji-t menunjukan $t_{\text {hitung }}=24,36$ dan $t_{\text {tabel }}=2,01$ untuk $\mathrm{db}=47$ pada taraf signifikansi $5 \%$. Berdasarkan kriteria pengujian, karena $t_{\text {hitung }}>\mathrm{t}_{\text {tabel }}$ maka $\mathrm{H}_{0}$ ditolak dan $\mathrm{H}_{1}$ diterima. Artinya, terdapat pengaruh yang signifikan model pembelajaran Open Ended berbasisTri Kaya Parisudha terhadap hasil belajar matematika siswa kelas V SD Gugus VI Kecamatan Sukasada Kabupaten Buleleng Tahun Pelajaran $2019 / 2020$.

Berdasarkan uraian di atas, hasil analisis data penelitian menunjukan terdapat pengaruh yang signifikan model pembelajarn Open Ended berbasis Tri Kaya Parisudha terhadap hasil belajar matematika siswa kelas V SD Gugus VI Kecamatan Sukasada Kabupaten Buleleng Tahun Pelajaran 2019/2020. Berdasarkan pengamatan pada tahapan penelitian yang telah dilaksanakan, model pembelajaran Open Ended berbasis Tri Kaya Parisudha dapat secara langsung melatih siswa untuk lebih terlibat secara aktif dan kreatif dalam proses pembelajaran. Hal ini dapat dilihat dari partisipasi siswa yang tinggi dalam proses pembelajaran yang telah dilaksanakan. Dapat dilihat minat belajar siswa menjadi lebih meningkat akibat penerapan salah satu model pembelajaran yang inovatif ini. Model pembelajaran ini sudah diaplikasikan dengan tepat sesuai dengan sintaks yang disusun sehingga mampu membuat siswa lebih aktif. Pembelajaran yang dilaksanakan diiringi dengan pembahasan permasalahan-permasalahan matematika yang konkret atau mudah ditemui dalam kehidupan sehari-hari. Dalam mendukung hal tersebut, juga digunakan benda-benda konkret atau media konkret yang berkaitan dengan permasalahan yang dibahas. Dengan demikian, siswa dapat berpikir sesuai dengan konteks permasalahan matematika yang dibahas tersebut. Mudahnya siswa dalam mencerna permasalahan yang konkret mengakibatkan siswa menjadi tertarik dan tertantang dalam memecahkan soal yang disajikan dalam permasalahan yang konkret tersebut. Kemampuan berpikir kritis siswa menjadi terlatih dan siswa berusaha dalam menggunakan kemampuannya tersebut. Terlebih, dengan permasalahan terbuka yang disajikan menyebabkan siswa mampu lebih mendalami konsep matematika yang terkandung dalam permasalahan tersebut.

Pada pembelajaran menggunakan model Open Ended berbasis Tri Kaya Parisudha, siswa bisa belajar dalam kelompok kecil. Dalam proses pembelajaran, siswa memahami dan menerapkan nilai-nilai penting konsep Tri Kaya Parisudha. Tiga landasan Tri Kaya Parisudha selalu ditekankan dalam membantu kelancaran siswa dalam pembelajaran. Dalam pengimplementasiannya, siswa sudah menerapkan ketiga konsep yang terkandung dalam ajaran Tri Kaya Parisudha pada setiap interaksi dalam proses pembelajaran, sehingga makna belajar menjadi lebih terasa. Manacika (berpikir yang baik) adalah bagian Tri Kaya Parisudha yang 
pertama. Pengimplementasian dalam pembelajaran yang telah dilakukan terkait konsep Manacika (berpikir yang baik) adalahsiswa sudah mampu berpikir yang baik terhadap pemahaman materi dan permasalahanpermasalahan yang telah diberikan. Sebelum merespons dan mendiskusikan permasalahan-permasalahan yang diberikan, siswa telah memikirkannya dengan baik terlebih dahulu. Bagian Tri Kaya Parisudha selanjutnya adalah Wacika (berkata baik).Pengimplementasian dalam pembelajaran yang telah dilakukan terkait konsep Wacika (berkata baik) adalah siswa mampu berbicara/berkomunikasi dengan baik. Berbicara/berkomunikasi dilakukan antara sesama siswa ataupun antara siswa dengan guru. Selain itu, siswa mampu saling bertanya dan menambahkan serta saling menghargai pendapat antara pihak yang terlibat dalam pembelajaran.Dengan hal tersebut, suasana belajar menjadi damai dan fokus dalam mencapai tujuan yang diinginkan. Bagian Tri Kaya Parisudha yang terakhir adalah Kayika (berbuat yang baik). Pengimplementasian dalam pembelajaran yang telah dilakukan terkait konsep Kayika (berbuat yang baik) adalah siswa terbiasa untuk berinteraksi yang baik dalam kelompok dengan menunjukan rasa kerjasama yang tinggi dan saling mendukung tanpa adanya sikap saling mengganggu. Selain itu, siswa mampu bertindak nyata aktif dalam pembelajaran seperti aktif maju ke depan kelas untuk tampil dalam memecahkan masalah yang diberikan. Perbuatan yang baik tersebut mendukung jalannya pembelajaran menjadi lebih baik. Secara umum, integrasi konsep Tri Kaya Parisudha adalah siswa dilatih untuk mengendalikan pikiran, perkataan dan perbuatan sehingga siswa memiliki tanggung jawab dalam berpikir, berkata dan berbuat yang baik saat aktivitas pembelajaran. Semua hal yang berkaitan dengan pembelajaran yang dilaksanakan telah terbukti menyebabkan perbedaan yang signifikan pada hasil belajar siswa setelah mengikuti pembelajaran yang dirancang dalam penelitian ini.

Secara umum penerapan model pembelajaran Open Ended berbasis Tri Kaya Parisudha dapat membuat siswa dapat mencapai tujuan pembelajaran matematika di SD. Seperti teori yang dikemukakan oleh (Ali, 2009) mengenai tujuan pembelajaran matematika di SD sebagai berikut. Tujuan pertama yaitu anak dapat secara aktif terlibat dalam proses belajar dan kesempatan untuk mengemukakan ide-ide mereka. Hal tersebut tercermin dari anak-anak telah mampu mencoba mengemukakan masalah-masalah yang berkaitan dengan materi yang dibahas. Tujuan kedua yaitu melatih karakteristik dan tahapan berpikir yang teridentifikasi dan dapat dipastikan bahwa anak melalui tahapan-tahapan tersebut. Hal ini tercermin dari anak telah mampu mengaitkan teori berdasarkan hal konkret yang telah anak alami, hal ini sesuai dengan tahapan berpikir siswa yaitu operasional konkret. Tujuan ketiga yaitu belajar bergerak dari tahapan yang bersifat konkrit ke tahapan yang lebih abstrak. Meskipun masih dalam tahap berpikir yang konkret, siswa juga telah dilatih berpikir lebih abstrak melalui konsep Open Ended yang siswa lakukan dalam menjawab soal permasalahan yang diberikan. Tujuan keempat, mampu untuk menggunakan simbol serta representasi formal serta alamiah berkembang dari tahapan yang lebih konkrit, Hal ini tercermin dari kemampuan siswa yang telah mampu mengaplikasikan rumus-rumus matematika dalam pembelajaran. Tujuan terakhir yaitu membentuk sikap logis, kritis, kreatif, cermat dan disiplin telah dilaksanakan sesuai tahapan-tahapan pembelajaran yang telah dirancang.

Temuan penelitian membuktikan pembelajaran pada kelas eksperimen dengan perlakuan model pembelajaran open ended berbasis Tri Kaya Parisudhadapat lebih meningkatkan hasil belajar siswa. Pembelajaran konvensional yang dilakukan pada kelas kontrol masih menunjukan aktivitas siswa yang cenderung pasif dan dominasi guru sebagai pusat pembelajaran masih kuat. Kondisi tersebut mempengaruhi hasil belajar siswa, dimana terdapat perbedaan yang signifikan hasil belajar siswa antara kelompok eksperimen dan kelompok kontrol.

Hasil penelitian ini juga sudah sejalan dengan kajian hasil penelitian relevan yang telah dilakukan sebelumnya.Seperti yang terdapat dalam hasil penelitian (Suwandi, Hasnunidah, \& Marpaung, 2016)menunjukan bahwa data hasil penelitiannya menyimpulkan penerapan model pembelajaran open ended memberikan pengaruh yang signifikan terhadap peningkatan kemampuan pemecahan masalah oleh siswa. Selain itu, data hasil penelitian yang sebelumnya dilakukan oleh (Lestari, Suniasih, \& Manuaba, 2017) menunjukan hasil analisis uji-t diperoleh thitung $=3,479>\operatorname{ttabel}(a=0,05,76)=2,000$, sehingga disimpulkan model pembelajaran open ended berbasis keterampilan menjelaskan berpengaruh terhadap kompetensi pengetahuan IPA pada siswa kelas V SD Gugus IV Jendral Sudirman Denpasar Selatan Tahun Ajaran 2016/2017. Kemudian penelitian yang dilakukan oleh (Nada, Utaminingsih, \& Ardianti, 2018) juga didapatkan hasil bahwa penerapan model pembelajaran open ended problem berbantuan CD pembelajaran dapat meningkatkan kemampuan berpikir kreatif siswa kelas IV.(Widana, N., Suhandana, A., \& Atmadja, 2013) menyimpulkan bahwa model open ended berpengaruh terhadap kemampuan berpikir kritis dan hasil belajar biologi siswa. Beberapa kajian penelitian relevan tersebut tersebut mendukungdan memperkuat bahwa hasil penelitian yang telah dilakukan telah sesuai atau sejalan dengan penelitian yang telah dilakukan sebelumnya. Inovasi dalam penelitian ini yang menjadi pembaharuan adalah dipadukannya model pembelajaran Open Ended dengan salah satu kearifan lokal yaitu 
Tri Kaya Parisudha dalam sebuah pembelajaran matematika di sekolah dasar. Teori-teori yang menjadi landasan dalam pelaksanaan penelitian ini juga telah dilaksanakan dengan tepat.

\section{SIMPULAN DAN SARAN}

Berdasarkan hasil pengujian hipotesis dan pembahasan, maka dapat disimpulkan bahwa terdapat pengaruh yang signifikan model pembelajaran Open Ended berbasisTri Kaya Parisudha terhadap hasil belajar matematika siswa kelas V SD Gugus VI Kecamatan Sukasada Kabupaten Buleleng Tahun Pelajaran 2019/2020. Kualifikasi hasil belajar matematika siswa yang dibelajarkan dengan model pembelajaran Open Endedberbasis Tri Kaya Parisudha memenuhi kategori sangat tinggi sedangkan hasil belajar matematika siswa yang tidak dibelajarkan dengan model pembelajaran Open Endedberbasis Tri Kaya Parisudha memenuhi kategori tinggi. Skor rata-rata hasil belajar matematika siswa yang dibelajarkan dengan model pembelajaran Open Endedberbasis Tri Kaya Parisudha lebih besar dari skor rata-rata hasil belajar siswa yang tidak dibelajarkan dengan model pembelajaran Open Ended berbasis Tri Kaya Parisudha. Jadi, pelaksanaan pembelajaran dengan model Open Ended berbasis Tri Kaya Parisudha memberikan pengaruh positif terhadap hasil belajar matematika siswa kelas VI SD Gugus VI Kecamatan Sukasada Kabupaten Buleleng Tahun Pelajaran 2019/2020. Terdapat beberapa saran yang dapat disampaikan berdasarkan penelitian yang telah dilakukan adalah sebagai berikut. Pertama, siswa dalam mengikuti proses pembelajaran hendaknya mempertahankan kemampuan yang telah diperoleh agar nantinya dapat meningkatkan hasil belajar dan memperoleh pengetahuan baru melalui pengalaman yang ditemukan. Kedua, guru dalam menyampaikan materi pelajaran di kelas hendaknya lebih berinovasi dan dapat memilih model pembelajaran yang mampu mengatasi permasalahan yang ada serta dapat memenuhi kebutuhan belajar sesuai dengan karakteristik siswa. Ketiga, kepala sekolah hendaknya dapat ikut serta memperkenalkan dan memberikan dorongan bagi guru-guru untuk menerapkan model-model pembelajaran inovatif, salah satunya adalah model pembelajaran Open Ended berbasis Tri Kaya Parisudha. Keempat, peneliti lain yang akan mengadakan penelitian lebih lanjut tentang model pembelajaran Open Ended berbasis Tri Kaya Parisudha dalam bidang pelajaran matematika maupun pelajaran lainnya yang sesuai hendaknya memperhatikan kendala-kendala yang dialami dalam penelitian ini dan dapat menambahkan inovasi terbaru sesuai dengan situasi dan kondisi penelitian yang akan dilakukan.

\section{DAFTAR PUSTAKA}

Agung, A. A. G. (2014). Metodologi Penelitian Pendidikan. Malang: Aditya Media Publishing.

Ali, M. (2009). Ilmu Dan Aplikasi Pendidikan Bagian Iii Pendidikan Disiplin Ilmu. Bandung: Imperial Bhakti Utama.

Amir, A. (2014). Kemampuan Penalaran Dan Komunikasi Dalam Pembelajaran Matematika. Logaritma: Jurnal Ilmu-Ilmu Pendidikan Dan Sains, Ii(1), 18-33.

Ardiyanti, N. P. R., Suarjana, I. M., \& Garminah, N. N. (2013). Pengaruh Model Pembelajaran Matematika Berorientasi Open-Ended Problem Terhadap Kemampuan Berpikir Kreatif Siswa Pada Mata Pelajaran Matematika. Mimbar Pgsd Undiksha, 1(1).

Artawan, K. N., \& Ardiawan, I. K. N. (2018). Pembelajaran Quantum Teaching Berbasis Tri Kaya Parisudha. Edudikara: Jurnal Pendidikan Dan Pembelajaran, 3(2), 201-212.

Biliya, B. (2015). Penerapan Model Open Ended Untuk Meningkatkan Keterampilan Proses Dan Hasil Belajar Siswa Kelas V Sdn 1 Repaking - Wonosegoro - Boyolali. Scholaria : Jurnal Pendidikan Dan Kebudayaan, 5(1), 78. Https://Doi.Org/10.24246/J.Scholaria.2015.V5.I1.P78-91

Delyana, H. (2015). Peningkatan Kemampuan Pemecahan Masalah Matematika Siswa Kelas Vii Melalui Penerapan Pendekatan Open Ended. Lemma, 2(1), 26-34.

Gunantara, G., Suarjana, M., \& Riastini, P. N. (2014). Penerapan Model Pembelajaran Problem Based Learning Untuk Meningkatkan Kemampuan Pemecahan Masalah Matematika Siswa Kelas V. Jurnal Mimbar Pgsd Universitas Pendidikan Ganesha, 2(1), 1-10. Https://Doi.Org/10.15294/Kreano.V10i2.19671

Heruman. (2007). Model Pembelajaran Matematika Di Sekolah Dasar. Bandung: Pt Remaja Rodaskarya. Kadir, A. (2015). Menyusun Dan Menganalisis Tes Hasil Belajar. Al-Ta'dib, 8(2), 70-81.

Khalistin, \& Hidayanto. (2013). Penerapan Pendekatan Pembelajaran Open Ended Untuk Meningkatkan Pemahaman Siswa Kelas Vii-A Smp Negeri 1 Batu Pada Materi Segi Empat. Universitas Negeri Malang, 1(1), 1-11.

Lestari, K. D., Suniasih, N. W., \& Manuaba, I. B. S. (2017). Pengaruh Model Pembelajaran Open Ended 
Jurnal Adat dan Budaya Vol. 2, No. 1, Tahun 2020, pp. 41-51

Berbasis Keterampilan Menjelaskan Terhadap Kompetensi Pengetahuan Ipa. Journal Of Education Technology, 1(3), 169. Https://Doi.Org/10.23887/Jet.V1i3.12501

M Desi Ariani, M Candiasa, A. M. (2014). Pengaruh Implementasi Open-Ended Problem Dalam Pembelajaran Matematika Terhadap Kemampuan.4(1), 1-11.

Marliani, N. (2015). Peningkatan Kemampuan Berpikir Kreatif Matematis Siswa Melalui Model Pembelajaran Missouri Mathematics Project (Mmp). Formatif: Jurnal Ilmiah Pendidikan Mipa, 5(1), 14-25. Https://Doi.Org/10.30998/Formatif.V5i1.166

Mujianto, S. (2017). Analisis Daya Beda Soal. Taraf Kesukaran, Butir Tes, Validitas Butir Tes, Interpretasi Hasil Tes Valliditas Ramalan Dalam Evaluasi Pendidikan. Jurnal Manajemen Dan Pendidikan Islam 2,2(2), 192-213. Retrieved From journal.unipdu.ac.id/index.php/dirasat/article/download/879/637\%0a\%0a

Nada, I., Utaminingsih, S., \& Ardianti, S. D. (2018). Penerapan Model Open Ended Problems Berbantuan Cd Pembelajaran Untuk Meningkatkan Kemampuan Berpikir Kreatif Siswa Kelas Iv Sd 1 $\begin{array}{lllll}\text { Golantepus. Jurnal Pendidikan Sekolah } & \end{array}$ Https://Doi.Org/10.30870/Jpsd.V4i2.3856

Noviyana, H. (2018). Pengaruh Model Open Ended Terhadap Kemampuan Pemecahan Masalah Matematis Siswa Smp. Jurnal E-Dumath, 4(2), 1-10.

Nuryanti, E. S. (2018). Optimalisasi Motivasi Dan Hasil Belajar Materi Menganalisis Teks Pantun Melalui Model Pembelajaran Open Ended Problems Learning Bagi Siswa Kelas Xi Mipa 5 Sman 1 Surakarta Semester 2 Tahun Pelajaran 2016/2017. Jurnal Konvergensi, 2, 55-68.

Parmanjaya, I. P. G. (2017). Ajaran Tri Kaya Parisudha Sebagai Landasan Pendidikan Nilai Moral Dan Etika Dalam Membentuk Karakter Anak. Purwadita, 1(1).

Rahmadani, N., \& Anugraheni, I. (2017). Peningkatan Aktivitas Belajar Matematika Melalui Pendekatan Problem Based Learning Bagi Siswa Kelas 4 Sd. Scholaria: Jurnal Pendidikan Dan Kebudayaan, 7(3), 241. Https://Doi.Org/10.24246/J.Scholaria.2017.V7.I3.P241-250

Rahmah, N. (2013). Hakikat Pendidikan Matematika. Al-Khwarizmi: Jurnal Pendidikan Matematika Dan Ilmu Pengetahuan Alam, 1(2), 1-10. Https://Doi.Org/10.24256/Jpmipa.V1i2.88

Riyani, R., Maizora, S., \& Hanifah, H. (2017). Uji Validitas Pengembangan Tes Untuk Mengukur Kemampuan Pemahaman Relasional Pada Materi Persamaan Kuadrat Siswa Kelas Viii Smp. Jurnal Penelitian Pembelajaran Matematika Sekolah (Jp2ms), 1(1), 60-65. Https://Doi.Org/10.33369/Jp2ms.1.1.60-65

Somawati, A. V., \& Diantary, N. M. Y. A. (2019). Implementasi Ajaran Tri Kaya Parisudha Dalam Membangun Karakter Generasi Muda Hindu Di Era Digital. Jurnal Pasupati, 6(1), 1. Https://Doi.Org/10.37428/Pspt.V6i1.135

Suardika, I. K. (2016). Pengembangan Video Pembelajaran Kebugaran Jasmani Berlandaskan Tri Kaya Parisudha. Jurnal Pendidikan Kesehatan Rekreasi, 2, 93-101.

Sundari, H. (2016). Model-Model Pembelajaran Dan Pemefolehan Bahasa Kedua/Asing. Jurnal Pujangga, $1(2), 106-117$.

Suwandi, T., Hasnunidah, N., \& Marpaung, R. R. T. (2016). Pengaruh Pembelajaran Berbasis Masalah Open-Ended Terhadap Peningkatan Kemampuan Pemecahan Masalah Oleh Siswa. Jurnal Pendidikan Progresif, Vi(2), 163-173.

Widana, N., Suhandana, A., \& Atmadja, B. (2013). Pengaruh Model Pembelajaran Berorientasi Pemecahan Masalah Open- Ended Terhadap Kemampuan Berpikir Kritis Dan Hasil Belajar Biologi Siswa Kelas Vii Smp Negeri 1 Kintamani . E-Journal Program Pascasarjana Pendidikan Ganesha, $4(1), 1-12$.

Yunus, M. (2015). Pengaruh Model Pembelajaran Open Ended Terhadap Hasil. Sigma, 1(2), 40-43. 